\title{
Teacher-Retraining Course Design Renewal
}

\author{
Elena Melekhina, Irina Kazachikhina \\ Novosibirsk State Technical University, Novosibirsk, Russia
}

\begin{abstract}
Teacher-retraining course design is considered to be a challenge not only to the course participants but to the course designers as well, especially, when the participants enrolled turn out to have dramatically different professional background and conditions. This article supports the idea that changes to the course design should be made straightaway in response to the trainees' specific needs. The context for rural school teacher retraining at Novosibirsk State Technical University in Russia illustrates reasons for making immediate changes necessary as the course progressed, and reaction to them. The article discusses a model for a teacher retraining course in which EFL improvement is the core element.
\end{abstract}

Keywords: teacher retraining program, rural teachers, shortage of EFL teachers, non-cohesive professional background, changers to course design

\section{Introduction}

It is no secret that a teacher is a key figure in any teaching process, be it in an urban or rural school. It is impossible to carry out educational reforms without teachers. They are responsible for achieving results set by national educational standards. The more professional teachers are, the better results their students demonstrate. And it is understandable why the Russian Federation State Standard of secondary education requires that "teachers who do not possess certified qualifications necessary to perform professional duties must take training or retraining course and be certified to prove their professional eligibility" (Russian Federation State Educational Standard of secondary education, 2012). To meet this requirement, universities launch training and retraining programs for the teachers of different subjects, particularly teachers of those subjects which are in great demand in schools like teachers of English as a foreign language.

No matter how many specialists majoring in teaching English graduate from pedagogical universities, there has been a shortage of EFL teachers in Russia for decades. Even the positive tendency of the recent years that is more teachers graduate from higher educational institutions comes to nothing. One of the reasons is that the graduates are not motivated by rather low salaries for novice teachers and big amount of tedious paper work school teachers have to carry out. Other reasons are connected with opportunities offered by the globalizing world to people with high proficiency in English. They can easily find jobs with better conditions and payment either in this country or overseas. That is why schools are in a difficult situation when, on the one hand, the paradigm of innovation spread over the world is confronting school system with the new range of professional

Elena Melekhina, Head of the Foreign Languages Department, Cand. of Sci. (Pedagogy), Novosibirsk State Technical University, Novosibirsk, Russia. Irina Kazachikhina, assistant professor, Cand. of Sci. (Philology), Novosibirsk State Technical University, Novosibirsk, Russia. 
competencies and calling for producing a school leaver of the innovative type acquiring English speaking skills as part of their life. On the other hand, there are not enough EFL teachers not to mention highly qualified ones.

To improve the situation with teaching English, school administration either stimulates teachers of other subjects to take courses in teaching English or makes EFL teachers master problem areas of their teaching practice if they lack the professional competencies required to teach. That is especially relevant to complex professional situations in rural schools. The small rural school reflects demographic, economic, and political conditions for the existence of the modern Russia; it determines largely the shape of the Russian school education. In Russia almost 40,000 are rural schools out of 59,000, whereas most rural schools are so-called ungraded ones. Schools with small classes in number of pupils exist in most countries. In Chervonnyi’ study, we find similar situations in many countries:

The international survey carried out by UNESCO in 1961 in 69 countries around the world, found that fifty-eight $(84 \%)$ of those have quite a high rate of rural schools in their school education systems. In each country, rural schools function according to the state educational policy and current educational practices in these countries. In many countries, small schools have proven their success and efficiency. In Norway, rural schools use effectively the system of the combined classes. In Australia, a network of small schools is maintained by radio. In Finland, the small schools rely on the tremendous support of the state, including the transportation of school children to the schools situated as far as hundreds of kilometers. In the United States the so-called one-room schools are based on the tradition of the absence of division into classes in accordance with the same age and peer tutoring. (as cited in Mihaylichenko, 2009, p. 19)

In the sparsely populated regions of Russia, for example, in Siberia small rural schools occupy most part in the school network. They are economically ineffective: to teach a pupil costs from 5 to 10 times more than average. To escape merging neighbourhood schools teachers have to be ready to develop various competencies that allow them to perform a variety of duties and even take charge of teaching several school subjects. (Mihaylichenko, 2009, p. 20). The present paper examines the problems rural school non-EFL teachers face while being retrained to become EFL teachers and solutions offered by their trainers at Novosibirsk State Technical University (NSTU).

\section{Context}

There is special referent to the Novosibirsk region and ELT context in Novosibirsk.

Novosibirsk region is situated in West Siberia, and covers an area of about 178 square kilometers. Novosibirsk ranks third in Russia in terms of population (after Moscow and St. Petersburg). According to the statistics, Novosibirsk region has a population of more than 2.5 million people, with 2 million of them living in the city of Novosibirsk and regionally subordinate towns. $76 \%$ of schools in the region are rural (Authorities of the Novosibirsk Region, 2015).

In 2013, the Ministry of Education and Science of the Russian Federation launched a project focused on improving situation with teaching English in rural schools. Novosibirsk State Technical University was a part of the project. The aim of the 10-month retraining course at the Faculty of Training and Retraining Programs and Department of Foreign Languages (Humanities Programs) at NSTU was to retrain 21 non-EFL rural school teachers (mostly teachers of the German, French, and Russian languages, but also of History, Geography, Psychology, and even Crafts), and give them a qualification to teach EFL in primary and secondary schools. The teachers were appointed to the course by their school authorities to fill EFL teacher vacancies. The length of the 
course was shorter than other available options in the Novosibirsk region and in Russia in general, therefore, the demand for EFL teachers was supposed to have met urgently. The other ways of being trained and certified as an EFL teacher in Russia are as follows:

(1) 2-year-and-10-month secondary professional program that allows teaching English in primary school only;

(2) 4-year-bachelor program that allows teaching English in primary and secondary school.

The globally recognized CELTA and TESOL certificates are still a rare case among the teachers who live and work in the city of Novosibirsk, nothing to say about rural school teachers. Besides, even if a teacher possesses a CELTA or TESOL certificate, it is not recognized as a TEFL qualification on the federal level in Russia rather than a proof of a valuable in-service course added to the formal EFL education qualifications.

The retraining course program focused on the modern language policy of the government, teacher's personal and professional development, ELT, and English language skills. The overall number of hours was 502 including 352 contact hours and 150 hours of self-study. The course under consideration lasted for 10 months and consisted of six sessions when the participants came to study to Novosibirsk for 7-10 days. In between sessions trainers and trainees communicated through the Di-Space 2.0 e-learning environment developed and supported by the NSTU Institute of Distant Learning. We were the three teacher trainers responsible for different modules of the course syllabus. Two of us holding the scientific degrees supervised the process of writing the graduation papers.

\section{Needs Analysis}

In order to investigate the trainees' needs and receive a course participant profile, we designed a questionnaire, which was given to each participant when they applied for the course.

Course participant profile:

(1) Average age: Most of the teachers are in the late twenties (24\%) and thirties (38\%), the least of them are in their forties and fifties (38\%);

(2) Working experience: $29 \%$ have less than five years of working experience, $19 \%$ less than 10 , and $32 \%$ more than 20;

(3) EFL education: Professional background differs greatly: from EFL teaching education to non-teaching one (see Table 1).

Table 1

Professional Background of the Course Participants

\begin{tabular}{|c|c|c|c|c|c|c|c|c|c|c|}
\hline \multicolumn{9}{|c|}{ Teaching education } & \multirow{2}{*}{\multicolumn{2}{|c|}{$\begin{array}{l}\text { Non-teaching } \\
\text { education }\end{array}$}} \\
\hline \multicolumn{3}{|c|}{ FL teaching education } & \multicolumn{2}{|l|}{$\begin{array}{l}\text { Language } \\
\text { education }\end{array}$} & \multicolumn{2}{|c|}{$\begin{array}{l}\text { Non-language main } \\
\text { teaching education, but } \\
\text { English included }\end{array}$} & \multicolumn{2}{|c|}{$\begin{array}{l}\text { Non-language } \\
\text { teaching education }\end{array}$} & & \\
\hline \multirow[t]{6}{*}{$\begin{array}{l}\text { EFL } \\
\text { teaching }\end{array}$} & $\begin{array}{l}\text { Primary school subjects } \\
\text { (English included) }\end{array}$ & 3 & $\begin{array}{l}\text { Russian and } \\
\text { Russian } \\
\text { Literature }\end{array}$ & 1 & $\begin{array}{l}\text { Geograghy (and } \\
\text { English) }\end{array}$ & 1 & $\begin{array}{l}\text { Primary school } \\
\text { subjects }\end{array}$ & 4 & Psychology & 1 \\
\hline & French (and English) & 1 & & & & & History & 1 & $\begin{array}{l}\text { Library } \\
\text { studies }\end{array}$ & 1 \\
\hline & German (and English) & 2 & & & & & Crafts & 1 & & \\
\hline & & 6 & & 1 & & 1 & & 6 & & 2 \\
\hline & & 13 & & & & & & & & \\
\hline & & & & 21 & & & & & & \\
\hline
\end{tabular}


Also, at the first meeting after the ice-breaking activity we brainstormed the burning issues of everyday teaching practice in small groups and made short presentations on clipboard papers before the class. Those papers were kept up to the end of the course to revise what problems were solved and what were still "burning".

(4) Problems in teaching and what helps to solve them.

One of the most pressing problems was insufficient English language proficiency. Participants stressed the need for more practice and lack of opportunity to have it in distant places of Novosibirsk region they lived and worked.

The next acute problem was inadequate knowledge of ELT methodology. In spite of the fact that all participants graduated pedagogical universities or colleges, that is they were accustomed to the fundamentals of pedagogy, psychology, and didactics, lack of the knowledge and skills in teaching English made them feel less confident, stressed, and frustrated.

The third on the list was the issue specified by the on-going process of educational reforms. The introduction of the Russian Federation State standard of secondary education involved revision of foreign language courses with subsequent changes in syllabuses, materials, and approach. The participants mentioned difficulties with setting objectives of the courses, material design, self-study structuring, and assessment procedures.

The fourth problem concerned the difficulties participants encountered while using ICT. Before the course, the majority of the group had never experienced e-learning, made PowerPoint presentations, and used search engines to go to the sites of professional interests.

The last but not the least of the problems common to all trainees was the low motivation to learning English among the students of some rural schools explained by parents' demotivating attitude to absolute uselessness, in their opinion, of learning a foreign language. They cannot afford to send their children to continue education at tertiary schools and believe that it is possible to manage without English while doing heavy manual work on the job in the country.

But the teachers had not only common problems, they also shared the same values and had similar attitude to teaching. For example, the main reasons why they agreed (some of them were forced by the school authorities) to do the retraining course were as follows: "become a professional and fluent speaker of English, and share my knowledge with children", "I just love my job", "I want to push boundaries of national stereotypes", "I am satisfied with the progress my students make every day and I'm proud of them", "I am happy that my profession is to teach English", restating J.A. Comenius's aphorism "I love what I teach and I love those whom I teach", etc. Their desire and intention to be involved in teaching English made them overcome some serious obstacles which they were aware of.

\section{Course Description}

The participants' needs analysis allowed us to make required changes referred to the non-cohesive group after the first session through organizing two groups of different language levels, focusing more on teacher self-development in the professional development module, and covering theoretical input through material development, micro-teaching, and observation in the methodology module. The method of conducting the training was experiential and reflective, sometimes loop input was used. As he teacher trainers we wanted to be flexible and cooperative, that is why, the curriculum was narrowed to the core areas of the modules. We changed 
the number of hours allocated to each of the four modules taken into consideration the participants' professional background (see Table 2).

Table 2

Course Content and Mode of Delivery Planned and Renewed

\begin{tabular}{|c|c|c|c|c|c|c|c|c|c|c|c|c|c|c|}
\hline \multirow[b]{2}{*}{ Modules } & \multicolumn{2}{|c|}{ Session 1} & \multicolumn{2}{|c|}{ Session 2} & \multicolumn{2}{|c|}{ Session 3} & \multicolumn{2}{|c|}{ Session 4} & \multicolumn{2}{|c|}{ Session 5} & \multicolumn{2}{|c|}{ Session 6} & \multicolumn{2}{|c|}{$\begin{array}{l}\text { Overall } \\
\text { contact hrs. }\end{array}$} \\
\hline & Plan & Fact & Plan & Fact & Plan & Fact & Plan & Fact & Plan & Fact & Plan & Fact & Plan & Fact \\
\hline $\begin{array}{l}\text { Modern language policy of } \\
\text { the government }\end{array}$ & 10 & 10 & 4 & 4 & $\begin{array}{l}12 \\
\mathrm{M} / \mathrm{A}^{*}\end{array}$ & $\begin{array}{l}4 \\
\mathrm{M} / \mathrm{A}\end{array}$ & & & & & & & 26 & 18 \\
\hline $\begin{array}{l}\text { Teachers' personal and } \\
\text { professional development }\end{array}$ & 8 & 8 & 12 & 4 & 10 & 4 & 10 & 6 & $\begin{array}{l}8 \\
\mathrm{M} / \mathrm{A}\end{array}$ & 4 & & $\begin{array}{l}16 \\
\mathrm{M} / \mathrm{A}\end{array}$ & 48 & 42 \\
\hline Developing EFL skills & 30 & 30 & 44 & 56 & 14 & 36 & 32 & 56 & 24 & $\begin{array}{l}30 \\
\mathrm{M} / \mathrm{A}\end{array}$ & $\begin{array}{l}30 \\
\mathrm{M} / \mathrm{A}\end{array}$ & & 174 & 208 \\
\hline ELT methodology & & & 10 & 6 & 12 & 4 & 28 & 8 & $\begin{array}{l}16 \\
\mathrm{M} / \mathrm{A}\end{array}$ & $\begin{array}{l}14 \\
\mathrm{M} / \mathrm{A}\end{array}$ & & & 66 & 32 \\
\hline $\begin{array}{l}\text { Preparation of graduation } \\
\text { papers }\end{array}$ & & & & & & & & & & & 30 & 50 & 30 & 50 \\
\hline Course assessment & & & & & & & & & & & 8 & 8 & 8 & 8 \\
\hline Session contact hrs. & 48 & 48 & 70 & 70 & 48 & 48 & 70 & 70 & 48 & 48 & 68 & 68 & 352 & 352 \\
\hline
\end{tabular}

Note. M/A-Module Assessment.

In this section we describe how the course met the trainees' needs in order of specified priorities.

\section{Practicing English Language}

Developing EFL skills module underwent great changes in number of hours allocated (see Table 2) as well as in structure and content (see Table 3).

Table 3

Changes Made to the Developing EFL Skills Module After Session 1

\begin{tabular}{llllll}
\hline & \multicolumn{3}{c}{ Developing EFL skills } & \multicolumn{2}{c}{ Developing EFL skills } \\
\cline { 2 - 6 } & Plan & Fact & \multicolumn{2}{c}{$\begin{array}{l}\text { Developing EFL speaking Developing EFL } \\
\text { \& reading skills }\end{array}$} & $\begin{array}{l}\text { Developing EFL } \\
\text { listening skills }\end{array}$ \\
\hline Session 1 & 30 & 30 & & & 14 \\
Session 2 & 44 & 56 & 28 & 10 & 8 \\
Session 3 & 14 & 36 & 18 & 14 & 14 \\
Session 4 & 32 & 56 & 28 & 4 & 4 \\
Session 5 & 24 & $30 \mathrm{M} / \mathrm{A}$ & 12 & & \\
Session 6 & $30 \mathrm{M} / \mathrm{A}$ & & & & \\
Overall contact hours & 174 & 208 & &
\end{tabular}

First of all, to make the content of the language practice more relevant to teachers' professional needs the topics of the Unified State Exam were included into the course. We also practiced different forms of interaction like individual, pair, or group work, traditional grammar translation method and communicative one. Such eclecticism was intentionally applied to make the trainees as students understand advantages and disadvantages of every form and method because we share the idea of Parrot (2005) that:

...there is no general 'right way to teach. Teachers need to take account of the ways in which their students are predisposed to learn and to recognize the range of different predispositions which may be found in most groups of learners. These differences may be cultural, relating to local educational and intellectual traditions, or may be individual, 
relating to personality factors or to the effects of specific prior experience of learning. Teachers also need to take account of the fact that the skills and knowledge learners need or want to acquire will depend on the purposes for which they are learning. (p. 1)

That is why, at the end of each class, the trainees reflected on what they were doing and how they felt about doing different kinds of traditional exercises and interactive tasks. Moreover, they formulated the objectives of the activities, which provided them with clearer insight into goal-oriented character of teaching.

In addition to acquiring knowledge and language skills, the trainees learned how to reflect on their own activity and results achieved, because to be an effective planner of one's own progress it is necessary to use reflection. Not all knowledge can be spoon-fed or given at a due time and with desired pace and consequence. The utmost function of human mind able to reflect is synthesizing, which is ability to combine different concepts and ideas into a new one. Being synthesized, a notion is processed by every person individually, which triggers the process of learning. Reflection and synthesis help learners to feel that they are in control of and responsible for their learning.

Following Wallace (1991), we believe that reflection on professional action increases teachers' professional competence, helps them find their own professional style, adequately evaluate individual activity, make forecasts and analyze progress as well as stimulate self-control. So, on the course the trainees regularly reflected on their learning and teaching either by writing short reflective essays or through discussions in small groups or as a class.

As for the synthesizing, we used it to make semantic network or clusters on the basis of the material learned. The comparison of semantic networks made individually and discussed in small groups demonstrated not only the depth of understanding of the material learned but also the skills to organize it for better memorizing.

\section{Mastering ELT Methodology}

According to Westwood (2008), "there are five areas in which skilled teachers display their expertise, which include presenting and explaining subject matter and ideas, questioning students during lesson time, giving feedback, strategy training and adapting or differentiating instruction" (p. 60). That is why, mastering ELT methodology was organized in active ("hands-on") form through changing roles of teachers and students while micro-teaching different language aspects and skills. At the lessons on methodology the trainees' attention focused on their real life professional situations and difficulties they experienced in teaching, such as teaching language aspects or skills, assessment, raising learners' motivation, dealing with students' disruptive behaviour, etc.

To meet the retraining course participants' needs for moving innovation to the classroom, we exposed them to the innovations through the course. They experienced how to:

(1) Help a student to plan and monitor academic success;

(2) How to create favorable conditions for a student to meet educational objectives;

(3) How to maintain and manage constructive cooperation between subjects of the teaching/learning process;

(4) How to create and use effectively an educational environment/e-environment, how to develop professionally, including self-development.

But one of the main challenges for us as the teacher trainers was to determine the learning conditions that can help EFL learners - rural school teachers cope with their language anxiety. They felt nervousness and suffer 
from failing to speak EFL, some of them even teach. Peer-coaching approach, which made each participant act as both the coach and the coachee, provided us with the means to overcome the problem. When a participant felt expertise in some language/language skills areas, she acted as a coach. Thus, the learning environment became safe - supportive, developmental, and even confidential sometimes, and without evaluation feature. And this is in line with Robbins (1991), who writes that:

Peer coaching is a confidential process through which two or more professional colleagues work together to reflect on current practices; expand, refine, and build new skills; share ideas; teach one another; conduct classroom research; or solve problems in the workplace. Although peer coaching seems to be the most prominent label for this type of activity, a variety of other names are used in schools: peer support, consulting colleagues, peer sharing, and caring. (p. 1)

\section{Managing Secondary Education Reforms}

Educational reforms are meant to bring about changes which are introduced through state educational standards. According to Katz and Snow (2009), standards might be understood as tools for improving outcomes specified by the goals for improvement (as cited in Burns \& Richards, 2009, p. 67). The Federal State Educational Standard of Secondary Education introduced by the Ministry of Education of the Russian Federation in 2012 imposes requirements to develop a set of competencies through teaching a foreign language. Among those competencies are the following:

(1) Friendly and tolerate attitude to other culture values;

(2) National self-identification through learning about life of peers in other countries;

(3) Awareness of socially appropriate styles;

(4) Ability to use grammar, syntax and vocabulary to accomplish communicative goals according to a certain level of language competence;

(5) Ability to develop own strategy to mastering a foreign language, etc.

What is more, teachers of all subjects taught at schools are responsible for developing metadisciplinary competencies such as ability to set goals, plan future activity, cooperate with teachers and peers, study independently, and others.

To meet the trainees' needs to design and conduct EL courses according to the Standard Requirements, we suggested teachers compiling portfolios, which according to Evans (1995) is a collection of professionally relevant documents and materials to reflect and assess for defining trajectory of professional self-development (p. 11).

Our experience confirmed Richards and Farrel's (2005) belief that portfolio compiling engages teachers in the process of continuous and comprehensive self-assessment of their work (p. 99). The trainees filed the portfolios with excerpts from important documents and manuals, articles describing better practices of teaching, micro-teaching observation notes and materials from peers. Those materials were used as a frame of reference for evaluating teachers' day-to-day practice.

What is more, the trainees made a list of the useful Internet resources falling into such categories as "teaching materials", "laws and standards", "professional development", "free on-line books", "useful videos", etc. They proudly showed the portfolios to each other and photocopied files, if necessary.

The content of the portfolios was regularly discussed at classes and the trainees explained the reasons why they chose to file the materials. That kind of activity focused their attention on the purposefulness of what they were doing and how relevant it was to their professional situations. Eventually the trainees understood that 
portfolios could also be used as a means of assessing students' progress and achievements in acquiring language knowledge and developing competencies specified by the standard.

\section{Learning How to Teach With Technology}

In spite of the fact that all trainees used mobile phones as part of their daily life, for some of them a computer was not an integrated part of teaching process. That fact was explained by different reasons including insufficiency of computers in remote rural schools, unreliable Internet connection, and teachers' lack of knowledge and skills of using technology in a classroom.

As the needs analysis showed, teachers wanted to learn how to apply ICT to language learning and teaching, which is quite understandable because their learners belong to the generation of "digital natives". That is why, all our classes were held in rooms equipped with computers and multimedia projectors. The university Di-Space 2.0 e-learning environment provided opportunity for the participants to actively communicate both during sessions and in between, download materials from the course site, send fulfilled assignments, and practice language skills. Between sessions the trainees received teachers' feedback in written form and could see the lists of their grades with the scores for each particular assignment. Thus, being in the role of students, teachers learned how to use technology in learning and teaching English.

Also, while doing some tasks, the participants were supposed to use PowerPoint presentations, which was a new experience for some of them. At this stage peer-coaching helped to solve the problem of "inexperienced" presentation designers.

At this point, we cannot definitely say that the situation with incorporating technology into teaching English at schools where our trainees work has considerably improved. We say that they became aware of what technology can bring into classroom.

\section{Dealing With Learners' Motivation}

Motivation plays a main role in any success, be it in learning or any other business. While many scientists interpret this concept in different ways, motivation to learning languages, as defined by Gardner is "...a combination of effort plus desire to achieve the goal of learning the language plus favourable attitude towards learning the language" (as cited in Williams \& Burden, 2007, p. 116).

Through defining trainees' needs, we understood that sometimes they were facing negative attitude of some parents to learning a foreign language by children due to its uselessness in heavy agricultural work at remote villages. What is more, a foreign language is not an obligatory unified state exam like Russian language or mathematics. That is why the majority of learners do not choose it as an additional exam necessary to pass to enter a university.

That kind of situation cannot be solved by means of one teacher re-training course. It requires joint efforts of different structures at different levels of society organization, involving economy, politics, social welfare, and education.

What we really could do to change the situation with teaching English for the better was making the trainees understand the importance of learner-centeredness because it puts learners with their needs, abilities, and experience in the centre of teaching process. At the language practice classes, we did various tasks which might suit different types of learners' cognitive strategies and needs. We stressed the fact that whatever choice of tasks 
course books provide, the selection and/or modification of them is done according to teacher's beliefs. Teachers choose the way the activity is presented, whether it is done in groups or individually, whether creativity is permitted, and in what way to mediate different aspects of the task. And it is their responsibility to offer the tasks which meet individual learner's needs and raise motivation.

We also suggested organizing more extracurricular activities held in English for local communities involving parents and asking the trainees to brainstorm what kind of activities might suit their local context. They named such events as drama performances, singing songs and reciting poems at local festivals, celebrating the Christmas, April's Fool day, or Halloween with parents. The participants critically discussed the suggested ideas and wrote them down to motivate their students to learn English.

\section{Assessment}

To successfully complete the course, the trainees were supposed to fulfil seventy per cent of assignments, submit a portfolio of materials on modern language policy of the government module and a portfolio on teachers' personal and professional development module, pass developing EFL skills module and ELT methodology exams, write and successfully defend graduation paper. They managed to fulfil all the requirements with different scores amounting from "passed" to "excellent".

The topics of the course graduation papers involved different aspects of language learning and teaching, learners' motivation, classroom management, ICT application to teaching English, and so on. Most of the works were written on the basis of the trainees' professional experience, which made them more meaningful and professionally relevant.

\section{Course Evaluation}

Course evaluation was not just a traditional stage of a course and a natural element needed for revisiting a course structure and content, furthermore, the training probably would not even have happen at all or have taken a rationalist and academic orientation, if the course had not been evaluating continuously. The reason that made the in-service course unrealistic is obvious - dramatically different professional background. To remedy the situation, we used such instruments as:

(1) A group discussion (teacher trainers and trainees together);

(2) An interview to every trainee in private;

(3) The-end-of-the-module and the-end-of-the-course questionnaires to receive feedback on such aspects as "course content", "course structure", "trainers' performance", "use of technology", and "teaching methods";

(4) Reflection on the course participant's learning and progress through the course;

(5) Reflection on positive and negative moments occurred on the course/emotion trainees felt in the classroom.

Analysis of the data collected on the course evaluation and conclusions derived from the data are needed to be discussed separately. Here we would like to explain the reason we asked the trainees to reflect on positive and negative moments occurring on the course/emotions they felt in the classroom, and describe the way the reflection was conducted. Every teacher or teacher trainer knows that a cohesive group works more efficiently. As Session 1 showed, we had practically all characteristics of an unsuccessful group listed by Hadfield (1997), and some of them were as follows: 
There is an uncomfortable, tense, or negative atmosphere. The members of the group are all intent on their individual ambitions and are unwilling to compromise or define group goals for learning. Some group members do not participate in group activities. Some members of the group tend to dominate group activities at the expense of shyer members. Members of the group do not trust each other. Group members tend to be over-serious with little sense of fun. Group members lack confidence in themselves as learners, what they are learning, and the way they are being taught. (p. 11)

Firstly, we felt we needed to find some ways to get rid of the unnecessary guilt for keeping the trainees in the trap. We chose the strategies "Listening" and "Making sure all views are represented" (Hadfield, 1997, pp. 158-159), and developed a progression of reflection questions (see Appendix). To make the confrontation constructive, we took chances and conducted the first part of the reflection activity about negative moments occurring on the course/emotions the trainees felt in the classroom. We tried to carefully and gradually facilitate emotions with the questions which were supposed to make everyone share the responsibility for everything that was happening to us. While we were exploring the points of view, we were feeling solidarity and trying to offer some help to the trainees. The fact that the teacher trainers were listening to all negative things convinced the trainees of the good and firm intentions of the teacher trainers.

Secondly, to defuse tension, we definitely needed to try something positive together, for example, to share a sense of fun. So the participants were asked to identify some common points within the group looking at each other, concluding from being-together observations, making some suppositions about each other, or asking each other if necessary. The participants were really happy to identify so many things in common from hair style, names, place they live in, age, and so on. After a while, they realized they did the task partially because they found things in common with those sitting next to them. Then everyone looked at the whole group and almost together shouted "We are teachers!". They seemed puzzled first but then they started to repeat more confident "Right. We are teachers". Everyone realized that cooperatively we could cope with any situation.

Finally, it was time for trainees to give each positive feedback, i.e., reflect on positive moments occurring on the course/emotions they felt in the classroom. Trainees' frank sharing showed that the atmosphere had been changing to a positive and supportive one. That made it possible for everyone to feel interested in each other, listen to each other, and study cooperatively from Session 2 till the end of the course.

At the end of the course, we were interested in finding our trainees' attitudes to the retraining program and the importance of the achieved results for their career as EL teachers. When interviewed, the trainees positively responded saying the following: "the course helped us not only improve English but also build up confidence", "I think I can better understand my students now", "I like that the trainers and my colleagues were very understanding and supporting", "the program helped us get better insight into teaching", "we know how to deal with syllabus and where find materials", "I tried the activities that we did on the course with my students and they were a success", etc. We believe that positive evaluation of what teachers experienced on the in-service re-training course would serve as an engine in their professional self-development in general, and EFL skills in particular.

\section{Conclusion}

Though the present re-training course was provided by the university department, it did not bear any rationalist and academic orientation. We believe in such difficult conditions - in terms of non-cohesive group, time limit and urgency - the only way to reach learning outcomes was to change and implement a course program, 
as defined by Ur (1992), "to develop the professional theory of action of participants through integration of both practical and theoretical input, experience, and reflection" (Ur, 1992, p. 61). After struggling with the unexpected conditions during the first session of the course, strategically, we attempted to use group dynamics as an instrument of managing difficult situation to lead the group to a positive outcome; technically, we redesigned the course and built all modules of the course around developing EFL skills module as the core element. The approach, when the language component provides the input for the other course components, in particular language policy, professional development, and ELT methodology, offers simultaneously improvement of the teachers' command of the language as well as their professional skills of the teachers. The model we used is similar to one suggested by Cullen (1994), and "it may well provide an answer to the in-service training needs of teachers in many parts of the world" (p. 167).

\section{References}

Authorities of the Novosibirsk Region. (2015). Obshchie svedeniya (General information). Retrieved from https://www.nso.ru/page/2264

Cullen, R. (1994). Incorporating a language improvement component in teacher training programmes. ELT Journal, 48(2), $166-172$.

Evans, S. M. (1995). Professional portfolios: Documenting and presenting performance excellence. Virginia Beach, VA: Teachers' Little Secrets.

Hadfield, J. (1997). Classroom dynamics. Oxford: Oxford University Press.

Katz, A. M., \& Snow, M. A. (2009). Standards and second language teacher education. In A. Burns and J. Richards (Eds.), The Cambridge guide to second language teacher education (pp. 66-76). New York, NY: Cambridge University Press.

Mihaylichenko, A. Yu. (2009). Professional naya perepodgotovka uchiteley malokomplektnykh shkol (iz opyta raboty Tomskogo gosudarstvennogo pedagogicheskogo universiteta) (The professional development of teachers from small rural schools (from the experience of Tomsk State Pedagogical University)). Vestnik TPGU, 12(90), 19-21.

Ministry of Education and Science of the Russian Federation. (2012). Federal "nye gosudarstvennye obrazovatel" nye standarty obshchego obrazovaniya (Russian federation State Educational Standard of secondary education). Retrieved from http://standart.edu.ru

Parrot, M. (2005). Tasks for language teachers. Cambridge: Cambridge University Press.

Richards, J. C., \& Farrel, T. S. C. (2005). Professional development for language teachers. New York: Cambridge University Press. Robbins, P. (1991). How to plan and implement a peer coaching programme. VA: ASCD.

Ur, P. (1992). Teacher learning. ELT Journal, 46(1), 56-61.

Wallace, M. (1991). Training foreign language teachers. Cambridge: Cambridge University Press.

Westwood, P. (2008). What teachers need to know about teaching methods. Australia, Camberwell, Vic.: ACER Press.

Williams, M., \& Burden, R. L. (2007). Psychology for language teachers. Cambridge: Cambridge University Press. 


\section{Appendix}

Table 1

Reflection on Positive and Negative Moments Occurred on the Course/Emotions You Felt in the Classroom 1. Recall negative moments occurred on the courselemotions $\quad$ What do YOU think can be done to avoid it in future?
YOU felt in the classroom

Because of the program of the course

Because of the teachers trainers' fault

Because of YOUR fault as a course participant

Other

2. Look at each other attentively and try to identify what YOU have in common.

3. Recall positive moments occurred on the course / emotions Where/when/how do YOU think it can be used in future? YOU felt in the classroom

Thanks to the program of the course

Thanks to the teacher trainers

Thanks to YOU as a course participant

Other

Note. The order of questions given (first negative, then positive) is important, and relevant to the case described in the article. 